Rapid Communications

\title{
Direct Single-Cell Molecular Analysis of Plant Tissues by Video Mass Spectrometry
}

\author{
Mónica Lorenzo Tejedor, Hajime Mizuno, Naohiro Tsuyama, Takanori Harada, and \\ Tsutomu MasuJiMa ${ }^{\dagger}$
}

\author{
Graduate School of Biomedical Sciences, Hiroshima University, 1-2-3 Kasumi, Minami, \\ Hiroshima 734-8553, Japan
}

\begin{abstract}
Direct and quick molecular analysis of live plant single cells viewed under a video-microscope has been developed in their intact undamaged environment using nano-electrospray tip and mass spectrometers. This method has been successful in identifying specific molecules in plant live single-cell analysis by mass spectrometry, and opens the possibility to compare different cell types from different tissues with morphological evidence in undamaged plants.
\end{abstract}

(Received July 27, 2009; Accepted August 20, 2009; Published September 10, 2009)

\begin{abstract}
Analysis of the chemical composition of bulk plant extracts provides limited information, since the measured results are an average of all tissues present in the sample. Techniques that allow an analysis of the chemical composition of cell types, or even individual cells will enable new insights into the functional mechanism of plants, since cells of the same tissue behave in a different way even under the same condition. ${ }^{1}$ On the other hand, prior to their extensive use in the pharmaceutical industry, natural compounds with medicinal properties must undergo intensive testing, which requires time and resources. The primary screening of crude plant extracts, followed by guided fractionation, isolation of active components and structural elucidation of novel bioactive compounds, can take a long time since this specific analysis is tedious.

Cell-separating protocols, like the preparation of epidermal fragments, protoplasts or tissue peels, do not represent cells in their intact undamaged environment. Some protocols have already been developed for single-cell analysis, but are tedious. ${ }^{2}$ Mass spectrometry has become an outstanding tool for metabolic analysis at a single-cell level. ${ }^{3}$ By applying bioimaging together with mass spectrometry, we recently innovated a new successful approach for direct and fast live single-cell analysis. ${ }^{4,5}$ In this work, our technique was applied to plant single-cell analysis, providing direct, quick, versatile and non-destructive analysis of different cells that can be found in several layers of plant tissues. This allows having an analytical method that provides direct information at the cell level in real time. The plant tissue is not damaged in the analysis, and thus metabolic processes can be monitored with time within the same sample, a fact that cannot be achieved by the extraction of plant tissues. High-resolution mass spectrometers, such as a hybrid linear ion trap/Orbitrap mass spectrometer, have also been employed for the detection of both common and uncommon compounds. ${ }^{6,7}$
\end{abstract}

Pelargonium zonale, (synonym: Pelargonium $x$ hortorum), commonly known as garden geranium, leaves and leaf stalks were monitored by a CCD video camera mounted on a stereo microscope (OLYMPUS SZX12 or LEICA DFC 400). Cells of

† To whom correspondence should be addressed.

E-mail: tsutomu@hiroshima-u.ac.jp the leaf and leaf stalk were sucked into a gold-coated glass capillary nano-electrospray tip (Humanix, nanospray tip, Japan) set on a micro-manipulator (Narishige, MHW-103, Japan) using a syringe via tubing. For positive-mode detection, acetonitrile containing $0.5 \%$ formic acid was added as an ionization solvent to the sucked sample solution in the capillary nanospray tip.

Mass spectrometric detection was performed by a LTQ Orbitrap mass spectrometer (THERMO Fisher Scientific Inc.) equipped with a nano-ESI ion source. The spray voltage was set to around 1500 to $2000 \mathrm{~V}$, the resolution of the equipment was set at 100000 and the capillary temperature was set at $50^{\circ} \mathrm{C}$. The selected range of the measurement was $\mathrm{m} / \mathrm{z}, 100$ to 1000 . The MS/MS analysis was performed that the $[\mathrm{M}+\mathrm{H}]^{+}$ions were dissociated in the HCD (higher energy collision-induced dissociation) mode using the normalized collision energy at $55 \%$. A Fourier-transform manual calibration in the positive-mode was performed at the beginning of each group of measurements using polytyrosine; $\mathrm{m} / \mathrm{z}$ 182.08117, 508.20783, 997.397810. The obtained spectra were analyzed by XCALIBUR software (THERMO Fisher Scientific Inc.).

A nano-electrospary ionization (nano-ESI) tip was directly inserted into a single cell of Pelargonium zonale leaf stalk or leaf under a microscope. In the sucking process of the leaf, special care was taken to take the sample from a cell of the upper mesophyll trespassing the cuticle to suck its content (Fig. 1a). Similarly, the procedure was performed to suck cells of the different parts of the leaf stalk, as shown in the photographs of Fig. 1b. Then, samples were set to a nano-ESI attachment of the mass spectrometer for analysis. More than one thousand of the MS peaks out of a sample of around $1-5 \mathrm{pl}$ were detected, as shown in the spectra. All peaks from the samples were analyzed by statistic t-test for differentiating or extracting cell-specific and non-specific peaks. The t-test compares the intensities of a certain MS peaks between two sets of data groups. In this case, the peaks from leaf cell samples were compared versus leaf stalk cell samples (Fig. 1c). Those peaks that could be found only in the leaf or in the leaf stalk, corresponded to $\mathrm{t}$-values of $100 \%$ and $-100 \%$, respectively. The $t$-value is around zero (\%) if the peak is found in both samples with the same intensity.

Among all detected peaks, $\mathrm{m} / \mathrm{z} 169.12223(\Delta \mathrm{ppm}-0.451$, 


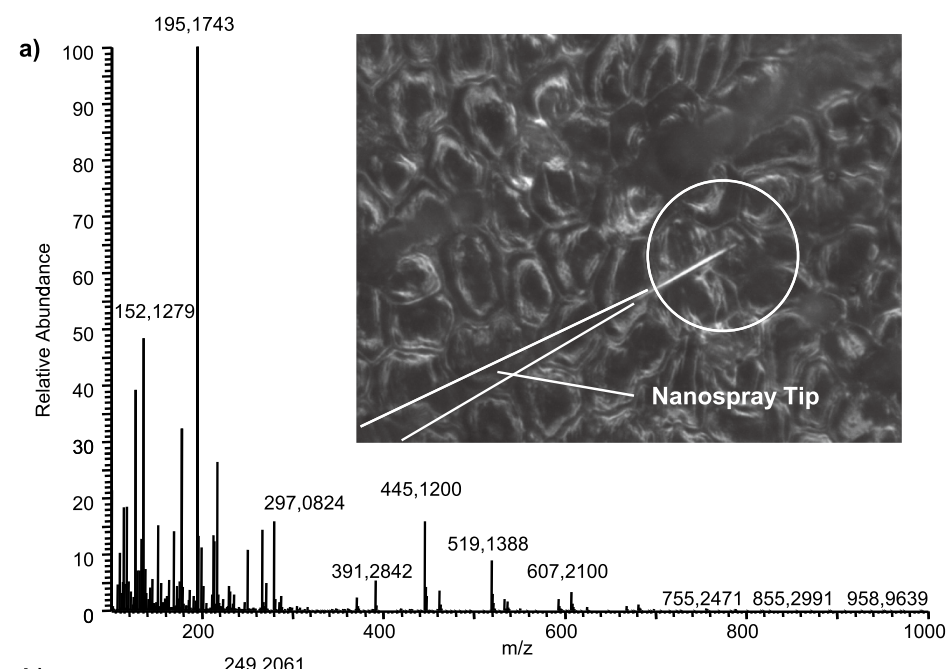

c)

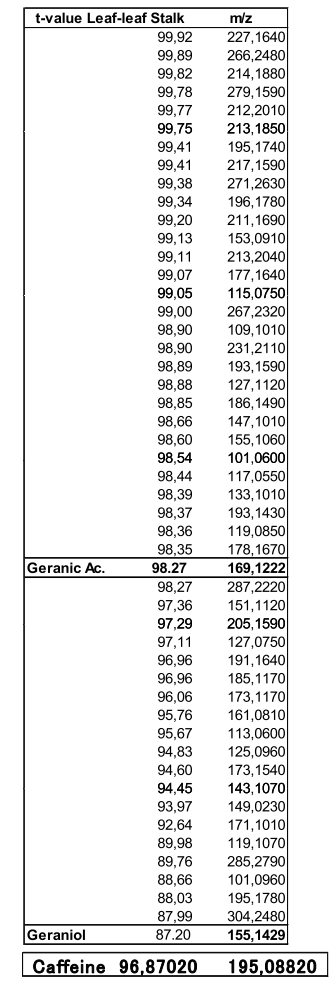

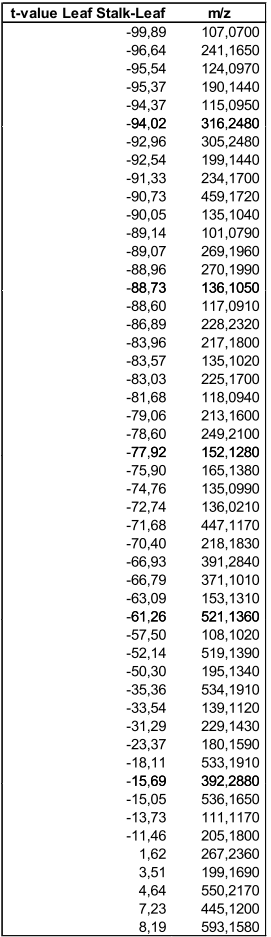

b) 100 年 249,2061

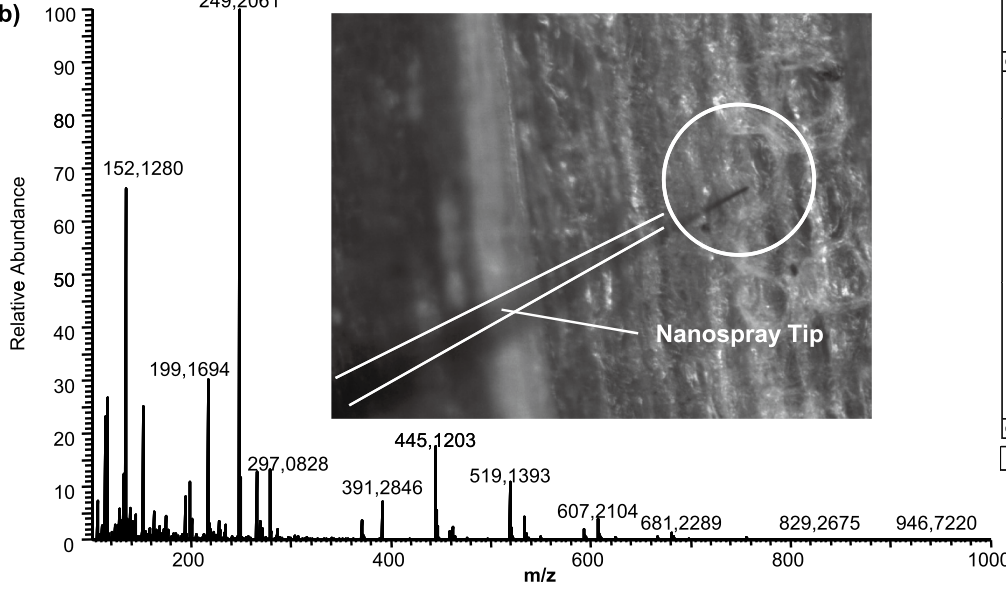

Fig. 1 Trapping of Pelargonium zonale single cell content by nano-ESI tip and comparison of spectra peaks detected by LTQ Orbitrap of a) leaf cell and b) leaf stalk cell. c) Table of summarized t-values for the peaks obtained in leaf and leaf stalk sample spectra after filtering of the minimum required intensity of $4 \mathrm{e}^{5}$ and detail of the caffeine peak t-value.

with 98.2704 t-value) was identified as geranic acid (3,7-dimethyl-2,6-octadienoic acid, $\mathrm{C}_{10} \mathrm{H}_{16} \mathrm{O}_{2}$ ) in its protonated form $[\mathrm{M}+\mathrm{H}]^{+}, \mathrm{m} / \mathrm{z}$ 155.14294 $(\Delta \mathrm{ppm}-0.656$, with 87.2064 t-value) was identified as a mixture of geraniol (3,7-dimethyl-2,6-octadien-1-ol, $\left.\quad \mathrm{C}_{10} \mathrm{H}_{18} \mathrm{O}\right)$ and $\alpha$-terpineol (2-(4-methyl-1-cyclohex-3-enyl)propan-2-ol, $\mathrm{C}_{10} \mathrm{H}_{18} \mathrm{O}$ ) in their protonated form $[\mathrm{M}+\mathrm{H}]^{+}$and $\mathrm{m} / \mathrm{z} 195.08820(\Delta \mathrm{ppm}-0.270$, with $96.8702 \mathrm{t}$-value) was identified as caffeine (1,3,7-trimethyl- $1 \mathrm{H}$-purine-2,6(3H,7H)-dione, $\left.\mathrm{C}_{8} \mathrm{H}_{11} \mathrm{O}_{2} \mathrm{~N}_{4}\right)$ in its protonated form $[\mathrm{M}+\mathrm{H}]^{+}$. It was found that geranic acid and caffeine are specific molecules in the leaf of the plant, while geraniol-terpeniol can be found in leaf stalk and leaf at the same time.

The MS/MS analysis was performed to confirm the elemental composition of the compound peaks. Standards were used to confirm the results. The HCD spectrum of the ion at $\mathrm{m} / \mathrm{z} 169$ shows product ions at $\mathrm{m} / \mathrm{z}, 127\left(\mathrm{C}_{7} \mathrm{H}_{11} \mathrm{O}_{2}\right), \mathrm{m} / \mathrm{z}, 123\left(\mathrm{C}_{8} \mathrm{H}_{11} \mathrm{O}\right)$, $m / z 95\left(\mathrm{C}_{6} \mathrm{H}_{7} \mathrm{O}\right)$ and $m / z \quad 85\left(\mathrm{C}_{4} \mathrm{H}_{5} \mathrm{O}_{2}\right)$. The $\mathrm{HCD}$ spectrum of the ion at $m / z, 195$ shows product ions at $m / z 177\left(\mathrm{C}_{7} \mathrm{H}_{6} \mathrm{O}_{2} \mathrm{~N}_{4}\right)$, $m / z, 163\left(\mathrm{C}_{7} \mathrm{H}_{7} \mathrm{ON}_{4}\right), m / z, 138\left(\mathrm{C}_{6} \mathrm{H}_{8} \mathrm{ON}_{3}\right), m / z 135\left(\mathrm{C}_{7} \mathrm{H}_{9} \mathrm{~N}_{3}\right), m / z$ $125\left(\mathrm{C}_{5} \mathrm{H}_{9} \mathrm{~N}_{4}\right), m / z \quad 121\left(\mathrm{C}_{5} \mathrm{H}_{5} \mathrm{~N}_{4}\right), m / z \quad 113\left(\mathrm{C}_{6} \mathrm{H}_{13} \mathrm{~N}_{2}\right), m / z 97$ $\left(\mathrm{C}_{5} \mathrm{H}_{9} \mathrm{~N}_{2}\right), m / z \quad 95\left(\mathrm{C}_{5} \mathrm{H}_{7} \mathrm{~N}_{2}\right), \mathrm{m} / z \quad 81\left(\mathrm{C}_{4} \mathrm{H}_{5} \mathrm{~N}_{2}\right)$, and $\mathrm{m} / z 69$ $\left(\mathrm{C}_{3} \mathrm{H}_{5} \mathrm{~N}_{2}\right)$ (Figs. 2a and $2 \mathrm{~b}$ ).

An analytical discussion can be developed with the peak at $\mathrm{m} / \mathrm{z} 155.14294\left(\Delta \mathrm{ppm}-0.656, \mathrm{C}_{10} \mathrm{H}_{18} \mathrm{O}\right)$, since two possible compounds, which can be found in the plant, ${ }^{8}$ can match these data of geraniol and $\alpha$-terpineol. The HCD spectrum of the peak at $\mathrm{m} / \mathrm{z} 155$ shows product ions at $\mathrm{m} / \mathrm{z} 137$ (geraniol/ $\alpha$-terpineol, $\mathrm{C}_{10} \mathrm{H}_{17}$ ), $m / z 111$ (geraniol $/ \alpha$-terpineol, $\mathrm{C}_{7} \mathrm{H}_{11} \mathrm{O}$ ), $m / z \quad 109$ (geraniol $/ \alpha$-terpineol, $\mathrm{C}_{8} \mathrm{H}_{13}$ ), $m / z \quad 98$ (geraniol, $\mathrm{C}_{7} \mathrm{H}_{15} / \alpha$-terpineol $\mathrm{C}_{6} \mathrm{H}_{11} \mathrm{O}$ ), $m / z, 97$ (geraniol $/ \alpha$-terpineol, $\mathrm{C}_{6} \mathrm{H}_{9} \mathrm{O}$ ), $\mathrm{m} / z 95$ (geraniol, $\mathrm{C}_{6} \mathrm{H}_{7} \mathrm{O} / \alpha$-terpineol, $\mathrm{C}_{7} \mathrm{H}_{11}$ ), m/z 93 (geraniol/ $\alpha$-terpineol, $\mathrm{C}_{7} \mathrm{H}_{9}$ ), $\mathrm{m} / z, 81$ (geraniol, $\mathrm{C}_{6} \mathrm{H}_{9}$ ), and $\mathrm{m} / z 67$ (geraniol, $\mathrm{C}_{5} \mathrm{H}_{7}$ ) (Fig. 2c). Due to the fact that the MS/MS data of the peak $\mathrm{m} / \mathrm{z} 155$ can be explained by the fractionation of the two stated compounds, the expected existence of a mixture of both products is given as a qualitative result.

The described method has been successful in identifying specific molecules in plant single cell analysis, and opens the possibility to compare different cell types from different tissues within undamaged plants by mass spectrometry which, together with morphological evidence, can directly unveil the molecular mechanism and dynamics of living organisms with higher speed and accuracy than at the present, thus avoiding the use of other analytical methods that could destroy the tissue of the study. We consider that many applications can be foreseen for the proposed protocol of analysis, such as quick quality control of crops, analysis of plant diseases and their treatment control, food analysis, quality control of medicinal plants and metabolism studies in biocompounds in medicinal plants used in pharmacology etc., which can be of interest in the present-day analytical field. 

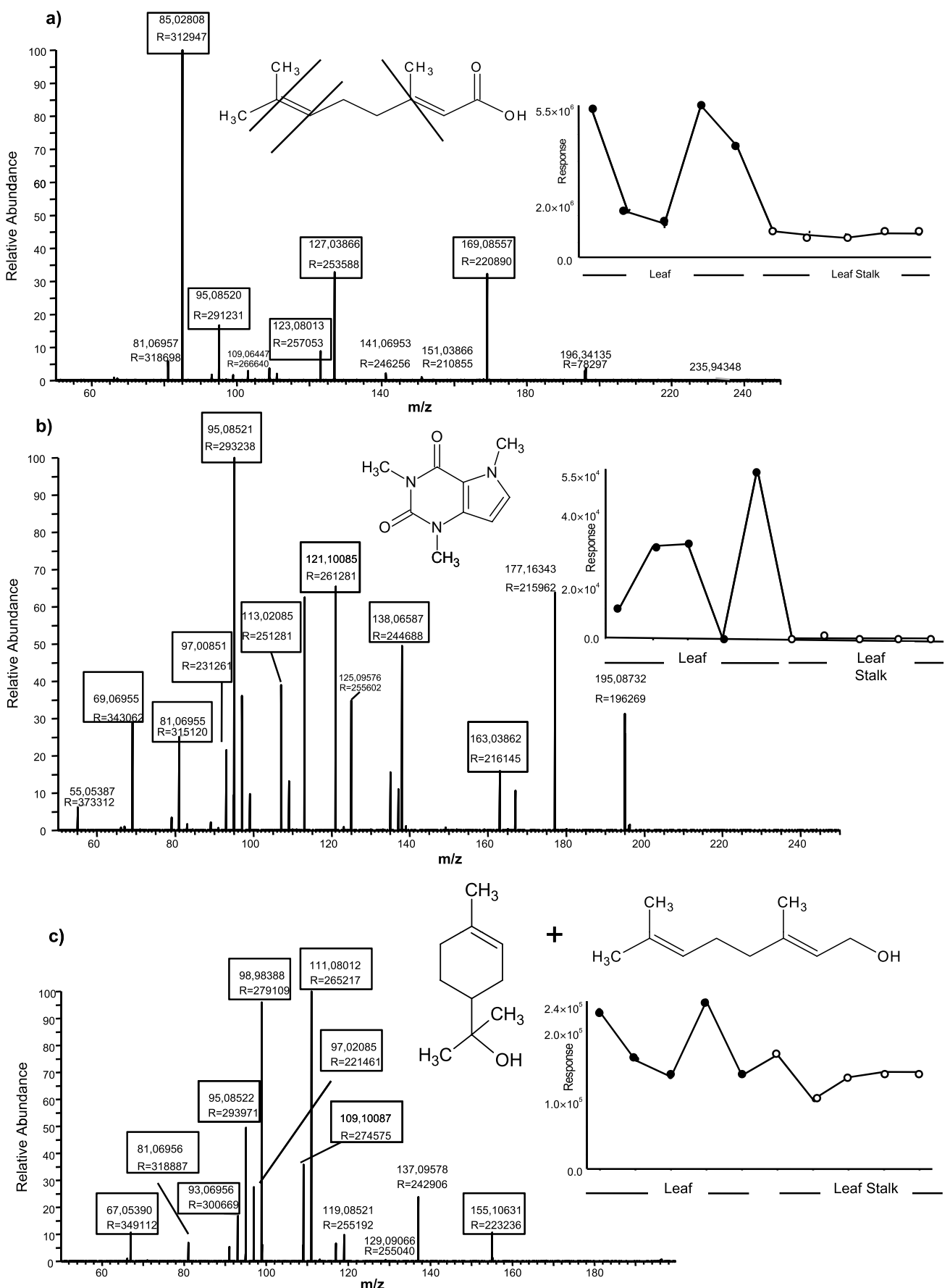

Fig. 2 MS/MS HCD spectra and t-value diagram for a) geranic acid, b) caffeine, c) geraniol and $\alpha$-terpineol mixture (R; peak resolution).

\section{Acknowledgements}

We thank Thermo Fisher Scientific Japan and Applied Biosystems Japan for their support in the instrumentation and data analysis, and the Research Center for Molecular Medicine and the Analysis Center for Life Sciences, Hiroshima University for the use of their instruments. This work was supported by the Grant-in-Aid (No. 20229003 (T. M.)) from the Ministry of Education, Science, Sports and Culture of Japan.

\section{References}

1. T. Masujima, Anal. Chim. Acta, 1999, 33, 400.
2. M. Malone, R. A. Leigh, and A. D. Tomos, Plant Cell Environ., 1989, 12, 919.

3. A. Amantonico, J. Y. Oh, J. Sobek, M. Heinemann, and R. Zenobi, Angew. Chem., Int. Ed., 2008, 47, 5382.

4. H. Mizuno, N. Tsuyama, E. Tokunaga, and T. Masujima, Anal. Sci., 2008, 24, 559.

5. H. Mizuno, N. Tsuyama, T. Harada, and T. Masujima, $J$. Mass Spectrom., 2008, 43, 1692.

6. A. Makaro, E. Denisov, A. Kholomeev, W. Balschun, O. Lange, K. Strupat, and S. Horning, Anal. Chem., 2006, 78, 2113.

7. A. Makarov, E. Denisov, O. Lange, and S. Horning, J. Am. Soc. Mass Spectrom., 2006, 17, 977.

8. A. Gauvin, H. Lecomte, and J. Smadja, Flavour Frag. J., 2004, 19, 455. 